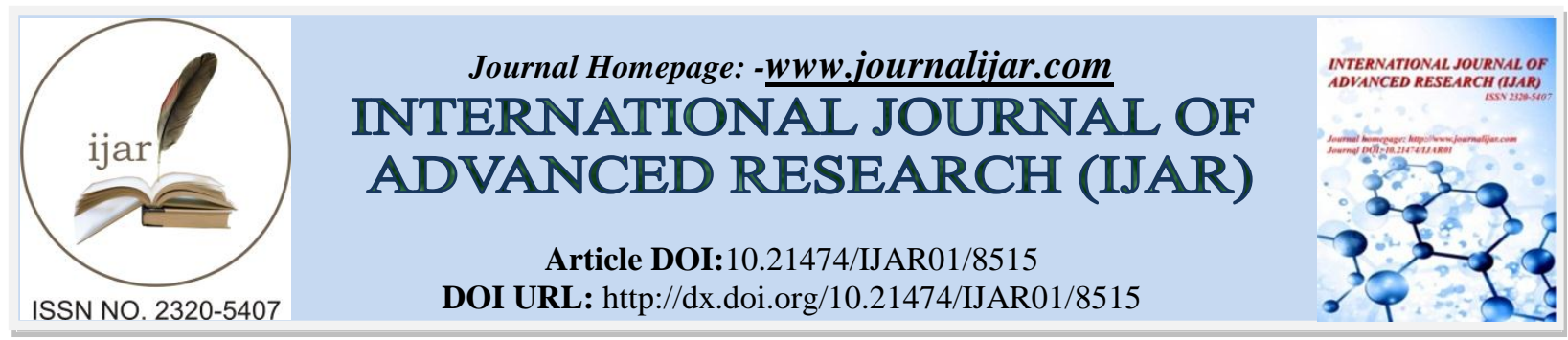

RESEARCH ARTICLE

\title{
CORPORATE GOVERNANCE MECHANISM ON FIRM PERFORMANCE THROUGH WORKING CAPITAL MANAGEMENT EFFICIENCY (WCME).
}

\section{Rosdiana $^{1}$, Abdul Rakhman Laba ${ }^{2}$, Muhammad Asdar ${ }^{2}$, Muhammad Sobarsyah ${ }^{2}$ and Reni Syamsuddin ${ }^{2}$.}

1. Faculty of Economics, Nuku University, Tidore, Maluku Utara, Indonesia.

2. Faculty of Economics and Business, Hasanuddin University, Makassar, Indonesia.

\section{Manuscript Info}

Manuscript History

Received: 06 December 2018

Final Accepted: 08 January 2019

Published: February 2019

Key words:

Board Characteristics, Audit Committee

Characteristics, WCM Efficiency and

Firm performance.

\section{Abstract}

The main objective of this study was to analyze and explain the implementation of corporate governance mechanism which includes board characteristics and audit committee characteristics as independent variables, the Working Capital Management Efficiency as mediating variable on the firm performance. This research was conducted at corporates in food and beverage, construction, botsudan, animal feed and gas industries located in Makassar.

This study used survey method in the collection of primary data. Purposive sampling was utilized in this study with a total sample of 90 respondents. Data were analyzed using regression analysis with Partial Least Square (PLS) - SEM technique.

The results showed that board characteristics had directly significant effect on firm performance while Audit committee characteristics had insignificant effect on firm performance. Indirectly, board characteristics have insignificant effect on firm performance through efficiency working capital management while audit committee characteristics have significant effect on firm performance through working capital management efficiency.

Copy Right, IJAR, 2019, All rights reserved.

\section{Introduction:-}

Corporate governance has been developed as an important mechanism in the company. However, the implementation of the Corporate Governance in most companies was weakened when the global financial crisis occurring. Nowadays, the demand for optimizing the Good Corporate Governance practice is essential, especially in conditions of industrial revolution are greatly influenced by technological aspects. Thus, several investors, board of directors and government regulators have encouraged companies to emphasize corporate governance from various sides such as accounting and finance, economics, law and management. However, regarding the mechanisms of governance used, they are different in each country. However, the most important aspect to properly manage the company whether it enters Asia, Europe or the United States is to apply the mechanism of Good Corporate Governance (GCG) to assist businesses in the decision making process (Cadbury Committee, 1992).

The control mechanism that helps the success of GCG and protects the interests of various stakeholders is Board of directors monitoring and financial report Audit. The board of directors is seen as the most important corporate governance mechanism that monitors and advises top management in carrying out their responsibilities to protect the 
interests of shareholders (Hermalin\&Weisbach, 2003), Financial report audits are main contribution to financial performance by providing adequate assurance that management financial statements are free from material misstatement, there by reducing the risk of significant misstatements and by ensuring that financial statements are described according to predetermined rules and regulations.

In addition to the audit, which is not less important, it is working capital management (WCM) because it is one of the most vital segments in the company's financing decisions as an important stimulus to the firm performance. The importance of WCM towards corporate achievement is considered a traditional concept that highlights all the company's standard financial textbooks (Aktas, et al., 2015).

\section{Problem Statement}

In connection with the research problems that have been described then in order to support empirical research, several research questions are proposed to be developed in this study, as follows:

1. Does board characteristics effect on firm performance in Makassar?

2. Does audit committee characteristics effect on firm performance in Makassar?

3. Does board characteristics effect on firm performance through WCM Efficiency?

4. Does audit committee characteristics effect on firm performance through WCM Efficiency?

\section{Research purposes}

The purpose of this study is:

1. To analyze the effect of Board Characteristics on firm Performance in Makassar.

2. To analyze the effect of audit committee characteristics on firm Performance in Makassar.

3. To analyze the effect of Board Characteristics on firm Performance through WCM Efficiency.

4. To analyze the effect of audit committee characteristics on firm Performance through WCM Efficiency.

\section{Literature Review and Hypotheses Development Agency Theory}

Agency theory is the basis used to understand corporate governance (Jensen 1993). Jansen and Meckling (1976) states that agency relations arise when one person or more (principal) employs another person (agent) to provide a service and then delegates decision-making authority to the agent. As an agent, managers are responsible for optimizing the profits of the owners (principals), but on the other hand managers also have an interest in maximizing their welfare.

In relation to the corporate governance aspect, agency theory approaches are most often used (Duhnfort, Klein et al. 2008). Agency Theory states that managers as agents of company owners take actions that only maximize their own interests if there are no other incentives or not monitored. If this happens, of course it will not be consistent with the aim of maximizing the value of the company. Amihud and Lev (1981) revealed that managers as agents of shareholders, do not always act in the name of the interests of shareholders because the objectives of both are different. The manager's well-being is very dependent on the size and risk of the company's bankruptcy. As a result, managers are interested in investing capital in order to increase growth and decrease the risk of the company through diversification, although this may not always improve the welfare of shareholders.

Jensen (1986) explains that the conflict of interest of managers with the interests of shareholders occurs with the assumption that the owners (shareholders) and agents (managers) each want a high return on investment projects but with different interests to risk. The difference to risk is explained by Amihud and Lev (1981) that shareholders have more interest in systematic risk, while managers have more interest in unsystematic risk.

\section{Stakeholder Theory}

Freeman and McVea (2001) define stakeholders as every group or individual who can influence or be influenced by the achievement of company goals. Thus, stakeholders can include a large group of participants. Actually, this applies to anyone who has a direct or indirect stake in this business. Stakeholders that must be considered in the governance structure include investors (including banks), managers, employees, customers, business partners (suppliers and subsidiaries), local communities, civil society (including regulators and pressure groups) and the natural environment. Relationships between companies and their internal stakeholders (such as employees, managers and owners) are framed by formal and informal regulations that have been developed during the relationship. Stakeholder theory supports the notion that companies and communities are interdependent and 
therefore corporations serve broader social goals than their responsibilities to shareholders (Kiel and Nicholson, 2003).

\section{Corporate Governance Mechanism}

According to Bank (1999), the mechanism of corporate governance control is divided into two, namely external and internal mechanisms. External mechanisms include: capital markets, funders, consumers, regulators. Walsh (1990) states that external control mechanisms are corporate controls based on market mechanisms (the market for corporate control), namely through capital market effectiveness (Fama, 1983), product and service markets and managerial resource markets (the managerial labor market) (Fama, 1980). Meanwhile, internal mechanisms include: control carried out by the board of commissioners (Fama, 1983) including committees under it, boards of directors, management, and shareholders, or through attractive and competitive incentive schemes for management.

Corporate governance mechanisms are related to tools, techniques and instruments that allow accountability to be ensured; These are a variety of media where stakeholders monitor and shape behavior to suit the goals and objectives set. Adekoya (2012) defines corporate governance mechanisms as "the processes and systems by which corporate laws and state corporate governance regulations are enforced". This study considers several corporate governance mechanisms from the board characteristics perspective and audit committee characteristics.

\section{Board's Characteristics}

Sharing the emphasis to connect configurations with internal and external contingencies, a relationship also emphasizes non-profit literature (Ostrower and Stone, 2009). The three characteristics of the board especially in the context of corporate governance are size of the board, board gender, and board diversity.

Board size is an important attribute of board effectiveness because larger councils have more resources than smaller councils to monitor managerial performance. As suggested by the resource dependency theory, larger councils appear to be better because they provide more information sources for directors and levels of environmental awareness that are not available to management (Muth, 1998). While small councils with a concentration of board positions can lead to a lack of transparency, a large number of board members, although increasing supervisory capacity, can harm the company by extending communication decision-making processes and procedures (Jensen, 1993)

\section{Audit Committee Characteristics}

The responsibilities of the audit committee include the assessment and evaluation of the company's ethical environment, financial information, compliance with regulations, and internal control systems and information. Obviously, the audit committee member must have the qualifications and expertise needed to give up this responsibility. As a result, audit committee members without accounting or financial knowledge may not be eligible to become members of the audit committee. Abbott (2000) recommends that at least one member must have accounting expertise or expertise related to financial management. Expertise is defined as past work experience in finance or accounting, professional certification required in accounting, or other comparable experience or background that results in individual financial sophistication, including being or having become a CEO or other senior official who has oversight financial responsibilities.

\section{Firm performance}

The concept of corporate performance needs to be distinguished from the construction of broader organizational effectiveness. Venkataraman and Ramanujam (1986) describe three concentric circles that overlap with the effectiveness of the largest organizations. The broadest domain of organizational effectiveness includes intermediate circles that represent business performance, which includes inner circles that represent financial performance.

Two other aspects must be considered when trying to define performance: the time frame and references. It is possible to distinguish between past and future performance. The superior performance of the past does not guarantee that it will remain superior in the future (Carneiro, Heckman et al., 2005). Another problem related to time is the duration of the interval (short, medium or long term) that is considered. 


\section{Hypotheses Development \\ Board Characteristics and Firm Performance}

The results of research conducted by several researchers have found uniform results including Bathula (2008) which examined the influence of Board Characteristics and Firm Performance. Evidence from New Zealand by taking ownership directors, $\mathrm{CEO}$ quality, gender diversity, $\mathrm{PhDs}$, board meetings and board size as the dependent variable provides evidence that board characteristics such as board size, CEO duality and gender diversity are positively related to company performance, where director ownership, board meeting and number of board members with $\mathrm{PhD}$ education levels are found to be negatively related. Borlea, Achim et al. (2017) who conducted a study using samples consisting of 55 Romanian non-financial companies registered in the Bucharest Stock Exchange (BSE) in 2012 found that there was no statistically significant relationship between board characteristics and performance.

H1: Board characteristics have insignificant effect on firm performance

\section{Audit Committee Characteristics and firm Performance}

An effective audit committee can ensure reliable financial reporting, strong internal control and functional risk management for the company. An effective audit committee can also help increase transparency in the securities market, thus providing better protection for shareholders' interests and improving company performance (Raghunandan and Rama, 2007). A competent, committed, independent and resilient audit committee has been described as one of the most desirable representatives of the public interest.

The results of Aldamen et al (2011) study, Duncan et al. (2012) show that audit committees are smaller with more financial experience and expertise is more likely to be associated with positive company performance on the market. They also found that the older audit committee chairman had a negative impact on accounting performance. Bouazis (2012) found evidence of the significance of the characteristics of audit committees on financial performance of Tunisian companies. Siam, Laili et al. (2015) found that companies with effective audit committee characteristics tend not to produce earnings management because opportunistic earnings cause uncertainty about the economic value of a company.

The literature review described above shows that the results of research on the influence of Audit Characteristics on the performance of the company show mixed results. Then the hypothesis proposed is as follows:

\section{H2: Audit committee Characteristics have significant effect on firm performance}

\section{Corporate governance Mechanism on firm performance through Working Capital Management Efficiency}

Gill and Biger (2012) conducted a study of the impact of corporate governance mechanisms on the efficiency of working capital management in American manufacturing companies. They use CEO tenure, CEO duality, and the size of the audit committee and board of commissioners to measure Corporate Governance. On the other hand, trade receivables, trade payables, CCC, efficiency of cash conversion and sales growth and current ratio are used to measure the efficiency of working capital management. They concluded that corporate governance increases the efficiency of working capital management of the company. The results of this study are supported by (Karani 2013) which shows that the application of corporate governance practices plays an important role in improving the efficiency of working capital management.

According to Achchuthan and Kajananthan (2013) there is no significant relationship between corporate governance and efficiency of working capital management. The results showed that the size of the board of directors, the structure of the board of directors and the board of commissioners did not significantly influence the efficiency of working capital management. In line with the results of the Achchuthan and Kajananthan study (2013), the results of the study by Kamau and Basweti (2013) also show that there is no statistically significant relationship between corporate governance and efficiency of working capital management.

The literature review described above is the basis for the author to put WCM Efficiency as mediating variable between corporate governance mechanisms (board characteristics and audit committee characteristics with company's performance considering that this hypothesis has never been done by previous researchers. The proposed hypotheses are as follows: 
H3: Board Characteristics have significant effect on firm performance through Working Capital Management Efficiency

H4: Audit committees have significant effect on firm performance through Working Capital Management Efficiency

The conceptual framework describes the relationship between the theoretical framework discussed earlier and the variables of Corporate Governance and company performance examined in this study.

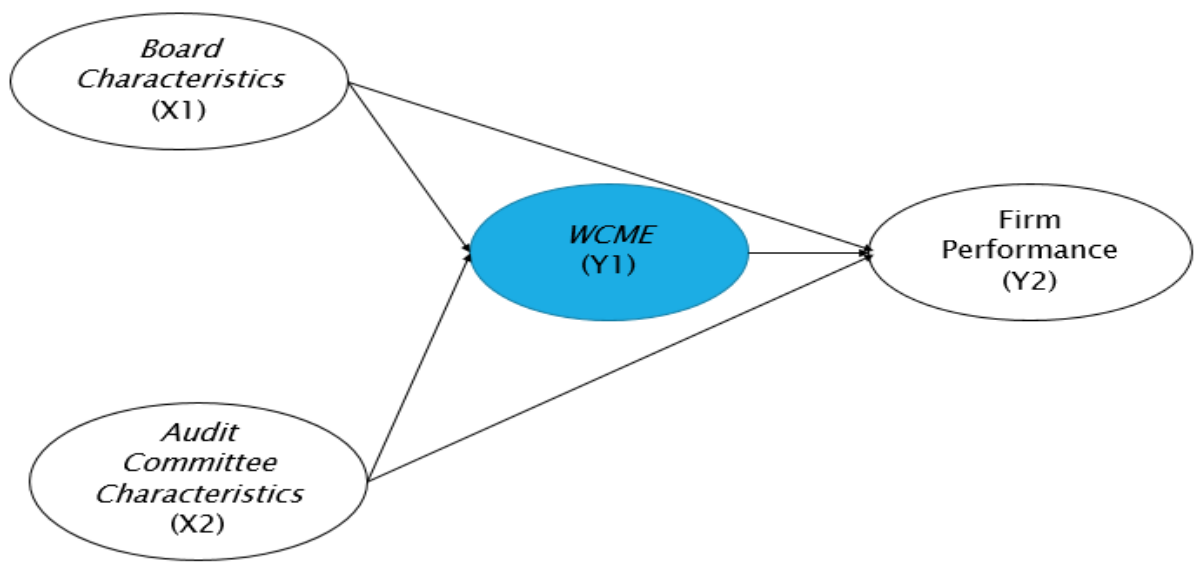

Figure 1: Conceptual framework

\section{Research Methods:-}

This research according to the level of exploration is included in the study of causality, because this study was conducted to test hypotheses regarding causality between one or several variables with one or several other variables (Neuman, 2014). This research was conducted at several corporate companies in Makassar which were carried out for 6 months starting from the initial data collection to completion.

This study uses a purposive sampling technique that has been used in previous research on corporate governance in various countries. This type of sample is one of the non-probability sampling techniques in the research sampling design and is based on specific objectives and characteristics that are appropriate for the sample. According to Neuman (2014), purposive sampling is appropriate if researchers have chosen their sample and want to reach an indepth understanding of the research topic. Based on the established criteria, the number of samples is 30 corporate companies registered in Makassar. The type of data used in this study is quantitative data and used two data sources namely primary and secondary sources; and data collection was done by using questionnaires.

Questions for this study use a five-point Likert scale, which is widely used in social science research (Saunders, Lewis et al. 2007), with the following values: $5=$ strongly agree or very significant, $4=$ agree or significant, $3=$ neutral, 2 disagree or not significant and $1=$ very disagree or very insignificant.

\section{Operational Definition and Research Indicators \\ Board Characteristics}

Board characteristics are a distinctive feature possessed by each member of the board in supervising and giving direction to the Board of Directors in order to run the management of the company based on the principles of Good Corporate Governance. The indicators used were adopted from Bathula (2008) which consist of board independence, board size, diversity of board members and manager's share ownership.

\section{Audit Committee Characteristics}

Audit Committee Characteristics is a characteristic that is owned by the audit committee in conducting supervision / monitoring. Competent, committed, independent, and resilient audit committee characteristics are described as one of the most desirable for the public interest (Levitt and Venkatesh, 2000). Previous literature states that Audit Committee (AC) also promotes and strengthens the existence of an internal audit function (Turley and Zaman, 
2004). The Audit Committee is an integral part of the corporate governance system required to review the financial reporting process. The role of AC is important for stakeholders because better reporting quality of financial reporting improves market performance. The indicators used were adopted from Siam, Laili et al. (2015) and Aldamen, Duncan et al. (2012) which consists of meeting frequency, auditor independence, auditor expertise and knowledgeable.

\section{Firm Performance}

Firm Performance is a result of a company's business process that shows the value of success of a business that can be measured by financial and non-financial information (Venkataraman and Ramanujam, 1986). The indicators used were adopted from Santos and Brito (2012), Al-Matari, Al-Swidi et al. (2014)) which consisted of profit rates, market value, growth rate, sales level of the company, number of new customers and the sustainability of the company.

The research model in full model can be described as follows:

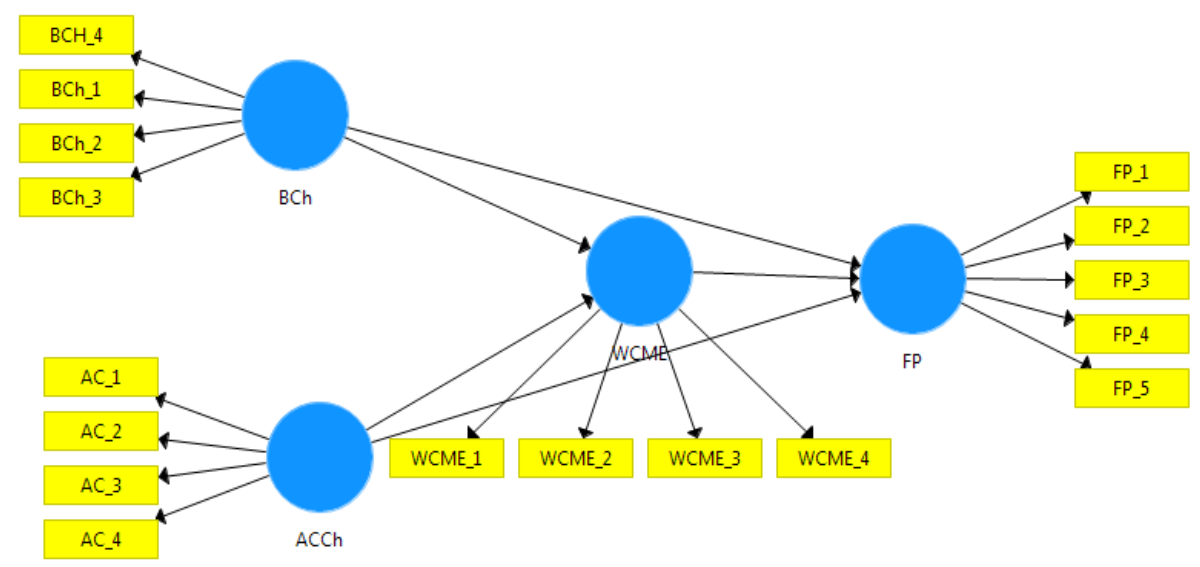

\section{Results And Analysis:- \\ Data analysis}

The collected data were analyzed using statistical test tools, namely variance-based structural equations test, better known as Partial Least Square (PLS) using Smart-PLS 3 software for the purpose of describing data and testing hypothesized relationships.

\section{Data Description of Respondents}

In accordance with the purposive sampling technique, there are companies that meet the criteria. Of the 90 companies the researchers were only able to visit as many as 50 companies because many companies whose addresses did not match the address listed on the database both at PT Kima and those in BPS, besides that many companies also intentionally did not install ID boards so that very difficult for researchers.

From 50 corporate companies, only 30 companies were willing to accept researchers so that the number of questionnaires distributed was 150 questionnaires with 5 respondents per company. After being analyzed and taking into account the completeness of the answers and the suitability of the criteria of the respondents, the sample set in this study amounted to 90 people for further processing which means that the number of respondents for each company was 3 people. The details are as follows:

Table 1:-Description of Respondent's Data

\begin{tabular}{|c|l|c|c|}
\hline No & Type of Corporate & Number of Corporate & Number of Respondents \\
\hline 1 & Food and beverage & 25 & 75 \\
\hline 2 & Construction & 1 & 3 \\
\hline 3 & Botsudan & 2 & 6 \\
\hline 4 & Animal Feed & 1 & 3 \\
\hline 5 & Gas & 1 & 3 \\
\hline
\end{tabular}




\begin{tabular}{l|l|r} 
Total & $\mathbf{3 0}$ & $\mathbf{9 0}$
\end{tabular}

\section{Hypotheses testing}

Testing hypotheses is basically to test theories based on empirical evidence in the field. From the results of data processing, it can be seen the magnitude of the relationship between exogenous variables towards endogenous both direct relationships, indirect relationships

Table 4:-Direct Effect

Path Coefficients

\begin{tabular}{|c|c|c|c|c|c|c|c|c|c|c|c|}
\hline \multirow[t]{2}{*}{ 闻 } & \multicolumn{2}{|c|}{ Mean, STDEV, T-Values, P-Va... } & 固 & \multicolumn{2}{|c|}{ Confidence Intervals } & 圂 & \multicolumn{2}{|c|}{ Confidence Intervals Bias $\mathrm{C}$. . } & \multirow[t]{2}{*}{ 圂 } & \multirow{2}{*}{$\begin{array}{l}\text { Samples } \\
\text { P Values }\end{array}$} & \multirow[t]{2}{*}{ Copy } \\
\hline & & \multicolumn{2}{|c|}{ Original Sampl... } & Sample Mean (... & \multicolumn{3}{|c|}{ Standard Devia... } & T Statistics $(\mid \mathrm{O} \ldots$ & & & \\
\hline & $\mathrm{CCh} \rightarrow \mathrm{FP}$ & 0.2 & & 0.224 & & & 0.136 & 1.695 & & 0.091 & \\
\hline & $\mathrm{CCh}->$ WCME & 0.7 & & 0.769 & & & 0.058 & 13.382 & & 0.000 & \\
\hline & $\mathrm{Ch}->\mathrm{FP}$ & 0.2 & & 0.224 & & & 0.113 & 1.980 & & 0.048 & \\
\hline & h $\rightarrow$ WCME & 0.1 & & 0.113 & & & 0.066 & 1.623 & & 0.105 & \\
\hline & $C M E->F P$ & 0.3 & & 0.359 & & & 0.138 & 2.491 & & 0.013 & \\
\hline
\end{tabular}

Table 5:-Indirect Effect

\section{Specific Indirect Effects}

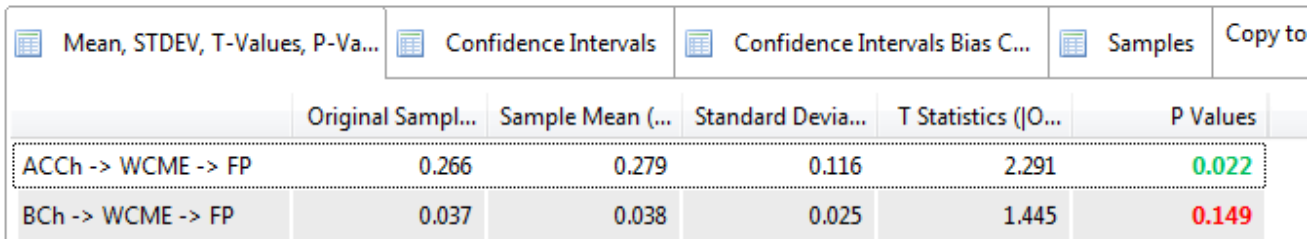

Source: Results of 2018 data processing

\section{Board Characteristics Effect on Firm Performance}

Statistical test results show that the board characteristics variable have a significant value of 0.048 smaller than 0.05 or a t-count value of 2.085 greater than t-table of 1.974 which means that board characteristics variables have a positive and significant effect on firm performance. The size of the board characteristics effect on firm performance is 0.178 or $17.8 \%$, which means that if there is an increase in board characteristics, the company's performance will also increase by $17.8 \%$;

This proves that $\mathrm{H} 1$ which states that Board characteristics have no effect on firm performance is rejected so that the results of this study is inconsistent with the results of research conducted by Borlea et al (2017).

\section{Effect of Audit Committee characteristics on firm Performance}

From the test results as shown in table 4 shows that audit committee characteristics variables have a significant value of 0.091 greater than 0.05 or t-count value of 1.841 smaller than $\mathrm{t}$-table 1.974 which means that audit committee variables have a positive and insignificant effect on firm performance. The magnitude of the influence of the audit committee on firm performance is 0.239 or $23.9 \%$, which means that if there is an increase in audit committee characteristics, the firm performance will not increase by $23.9 \%$. This proves that $\mathrm{H} 2$ which states that audit committee characteristics have a positive and significant effect on rejected firm performance so that the results of this study are in line with the results of research conducted by Laili et al. (2015) which states that companies with the characteristics of an effective audit committee tend not to produce earnings management because opportunistic earnings cause uncertainty about the economic value of a company.

\section{Effect of Board Characteristics on Firm Performance through WCM Efficiency}

From the results of testing on hypothesis 3 (H3) about the influence of board characteristics on firm performance through WCM Efficiency indicated by a coefficient of 0.037 and p-values of 0.149 , it is not in the same coefficient as the hypothesis statement, which means a positive and insignificant influence. The results showed that the existence of WCM Efficiency did not succeed in mediating the influence of Board characteristics on firm 
performance, thus indicating that the application of board characteristics in the management of the company through WCM Efficiency would reduce firm performance. Thus based on the results of testing empirically, then hypothesis 3 (H3) is declared rejected. The results of this study are not in line with previous research, Gill and Biger (2012) who applied co-relational research design. Samples were selected from 180 American manufacturing companies listed on the New York Stock Exchange (NYSE) for a period of 3 years (from 2009-2011) indicating that corporate governance, especially board characteristics, played several roles in improving the efficiency of working capital management.

\section{Effect of Audit Committee Characteristics on Firm Performance through WCM Efficiency}

The results of testing on hypothesis 4 (H4) about the influence of Audit committee characteristics on firm performance through WCM Efficiency are indicated by a coefficient of 0.232 and p-values of 0.022 , in the same direction as the hypothesis statement, which means a positive and significant influence indicating that indirectly the existence of WCM Efficiency is able to play a role as a mediating variable in the relationship between audit committee and firm performance. The results of this study indicate that the more appropriate the implementation of audit committee characteristics in the company's operations through the efficiency of working capital management will improve the performance of the company. This confirms that the position of the WCM Efficiency as a mediating variable that links audit committee characteristics to firm performance is strong. Thus based on the results of empirical testing, then hypothesis 4 (H4) is declared accepted. The results of this study are in line with the research conducted by Kamau and Basweti (2013) which shows that there is no statistically significant relationship between corporate governance and working capital management efficiency and is not in line with the results of research Karani (2013) shows that corporate governance specifically audit committee characteristics not influential in increasing the efficiency of working capital management so that it can improve the firm performance

\section{Conclusions:-}

From several tests that have been carried out, the conclusion of this study is that of the several hypotheses tested there were three rejected hypotheses, namely $\mathrm{H} 1$ (board characteristic have significant effect on firm performance). H2 (Audit Committee have insignificant effect on firm performance), and H3 (Board Characteristics have insignificant effect on firm performance through WCM Efficiency), while the accepted hypothesis is H4 (Audit Committee Characteristics have significant effect on firm performance through WCM Efficiency).

\section{Limitation and Recommendation}

The limitation in this study is because the number of samples used is small (90 samples), this is because many targeted companies are unwilling to accept researchers on busy grounds. For this reason, it is recommended that the next researcher use a larger sample so that the results obtained are more accurate.

\section{References:-}

1. Abbott, L. J. e. a. (2000). "The Effectiveness of Blue Ribbon Committee Recommendations in Mitigating Financial Misstatements: An Empirical Study." 1-29.

2. Achchuthan, S. a. and R. Kajananthan (2013). "Corporate Governance Practices and Working Capital Management Efficiency: Special Reference to Listed Manufacturing Companies in Srilanka." International Journal of Business and Management Review1: 72-85.

3. Aktas, N., et al. (2015). "Is working capital management value-enhancing? Evidence from firm performance and investments." Journal of Corporate Finance30: 98-113.

4. Al-Matari, A., Yahya, et al. (2012). "Board of Directors, Audit Committee Characteristics and Performance of Saudi Arabia Listed Companies." International Review of Management and MarketingVol. 2, No. 4: 241-251.

5. Aldamen, H., et al. (2012). "Audit committee characteristics and firm performance during the global financial crisis." Accounting \& Finance52(4): 971-1000.

6. Amihud, Y. and B. Lev (1981). "Risk reduction as a managerial motive for conglomerate merger." The Bell Journal of Economics12(1): 605-617.

7. Bathula, H. (2008). "Board Characteristics and Firm Performance: Evidence from New Zealand."

8. Borlea, S. N., et al. (2017). "Board characteristics and firm performances in emerging economies. Lessons from Romania." Economic Research-Ekonomska Istraživanja30(1): 55-75.

9. Bouazis, Z. (2012). "The Impact of the Presence of Audit Committees on the Financial Performance of Tunisian Companies." InternatIonal Journal of ManageMent \& BusIness studIesVol. 2(4): 57-64. 
10. Dühnfort, A. M., et al. (2008). "Theoretical Foundations of Corporate Governance Revisited: A Critical Review." Corporate Ownership \& Control6(2): 424-433.

11. Fama, E. F. J., Michael C (1983). "SEPARATION OF OWNERSHIP AND CONTROL." Journal of Law and Economics26: 301-325.

12. Freeman, R. E. E. and J. McVea (2001). "A Stakeholder Approach to Strategic Management." SSRN Electronic Journal.

13. Gill, A. S. and N. Biger (2012). "The impact of corporate governance on working capital management efficiency of American manufacturing firms." Managerial Finance39(2): 116-132.

14. Jansen, M., J. and W. H. Meckling (1976). "Theory of the Firm: Managerial Behavior, Agency Costs and Ownership Structure." Journal of Financial Economics3: 305-360.

15. Jensen, M. C. (1986). "Agency Costs of Free Cash Flow, Corporate Finance, and Takeovers." The Market for Corporate Control7(2): 323-329.

16. Kamau, S. M. and K. A. Basweti (2013). "The Relationship Between Corporate Governance and Working Capital Management Efficiency of Firms Listed at The Nairobi Securities Exchange." Journal of Finance and Accounting4(19): 190-199.

17. Karani, K., Henry (2013). "A Research Project Submitted in Partial Fulfillment of the Requirements for The Award of Masters Degree in Business Administration (Mba), University of Nairobi." 1-60.

18. Levitt, S. D. and A. Venkatesh (2000). "An Economic Analysis of a Drug-Selling Gang's Finances." The Quarterly Journal of Economics: 755-789.

19. Muth, M. M. D., Lex (1998). "Stewardship Theory and board Structure: a Contingency Approach." Scholary Research and Theory Papers6: 5-28.

20. Neuman, L., M. (2014). "Social Research Methods: Qualitative and Quantitative Approache." Seventh Editio: 1-599.

21. Ostrower, F. and M. M. Stone (2009). "Moving Governance Research Forward: A Contingency-Based Framework and Data Application." Nonprofit and Voluntary Sector Quarterly39(5): 901-924.

22. Raghunandan, K. and D. V. Rama (2007). "Determinants of Audit Committee Diligence." Accounting Horizons21(3): 265-279.

23. Santos, B., juliana and L. A. L. Brito (2012). "oward a Subjective Measurement Model for Firm Performance." BAR - Brazilian Administration Review9(6): 95-117.

24. Siam, A., Yousef., et al. (2015). "The Relationship between Audit Committee Characteristics and Earnings Management among Jordanian Listed Companies: Proposing Conceptual Framework." Journal of Finance and Accounting6: 1-11.

25. Venkataraman, N. and V. Ramanujam (1986). "Measurement of Business performance in Strategy Research: A Comparison of Approachess." Academy of Management Review11(4): 801-814.

26. Walsh, J. P. a. S., James K (1990). "On The Efficiency of internal and External Corporate Control Mechanism." Academy of Management Review15: 421-458. 